\title{
PENGARUH STRES KERJA TERHADAP KINERJA PEGAWAI PADA PT. TASPEN (PERSERO) CABANG PEMATANGSIANTAR
}

\author{
Oleh: \\ Nora Christina Simangunsong \\ S1 Manajemen \\ Darwin Lie, Marisi Butarbutar, Efendi
}

Abstraksi

Rumusan masalah dalam penelitian ini adalah bagaimana tingkat stres yang dialami pegawai dan gambaran kinerja pegawai pada PT. Taspen (Persero) Cabang Pematangsiantar. Permasalahan ini dijawab dengan menggunakan desain penelitian lapangan dan penelitian kepustakaan, populasi sebanyak 30 responden, data kualitatif dan kuantitatif yang bersumber dari data primer yang diperoleh dari PT. Taspen (Persero) Cabang Pematangsiantar dan data sekunder yang diperoleh dari buku-buku. Adapun teknik pengumpulan data dengan teknik kuesioner, wawancara, dokumentasi, serta teknik analisis data yakni analisis deskriptif kualitatif dan analisis deskriptif kuantitatif yang digunakan adalah regresi sederhana, korelasi, koefisien determinasi, dan uji hipotesis atau uji t.

Berdasarkan hasil analisa regresi $\hat{Y}=0,27-1,86 \mathrm{X}$ diperoleh pengaruh yang negatif antara stres dan kinerja, nilai koefisien determinasi yang diperoleh adalah sebesar 56,25\% tinggi rendahnya kinerja dapat dijelaskan stres. Perhitungan uji $t_{\text {hitung }}$ diperoleh 9,090 dan $t_{\text {tabel }}$ 2,048 dimana $t_{\text {hit }}>t_{\text {tab }}$ menunjukkan ada pengaruh yang negatif antara stres terhadap kinerja pegawai dengan kata lain $\mathrm{H}_{0}$ ditolak. Dari hasil evaluasi diketahui bahwa ada beberapa pegawai yang sering datang terlambat karena urusan pribadi, dan kurang bertanggung jawab dengan tugasnya. Berdasarkan hal ini Penulis memberikan saran agar Pimpinan lebih tegas dalam menegur para pegawai yang tidak disiplin, serta memotivasi dan menjalin hubungan komunikasi yang baik dengan para pegawai, agar tercipta suasana kerja yang kondusif.

Kata Kunci: Stres Kerja dan Kinerja

\section{Abstraction}

Internal issue formula in this research is how natural storey level stress of officer and picture of officer performance at PT. Taspen (Persero) Branch the Pematangsiantar. This Problems is replied by using desain of field research and library research, population as much 30 responder, data qualitative and quantitative steming from primary data obtained from PT. Taspen (Persero) Branch the Pematangsiantar and data secunder obtained from book. As for technique of data collecting with the technique questionnaires, interview, documentation, and also technique analyse data with descriptive analysis qualitative and quantitative descriptive analysis by simple regresi, correlation, coefficient determinasi, and test the hypothesis or test the $t$.

Pursuant to result analyse the regresi $\hat{Y}=0,27-1,86 X$ obtained a negative influence between stress and performance, assess the coefficient determinasi obtained is equal to 56,25\% lower the explainable performance with stress. Calculation test the $t_{\text {hitung }}$ obtained 9,090 and $t_{\text {tabel }} 2,048$ where $t_{\text {hit }}>t_{\text {tab }}$ show there is negative influence between stress to officer performance equally $H_{0}$ refused. From result evaluate known that there are some officer which often come lost time because private affair, and less hold responsible with its duty. Pursuant to this matter, Writer give the suggestion so that Head more coherent in admonishing all officer which not discipline, and also motivate and braid the good communications relation with all officer, so that created a job atmosphere which kondusif.

Keywords: Work Stress and Performance

\section{A. Pendahuluan}

\section{Latar Belakang Masalah}

Sumber daya manusia merupakan aset yang paling penting bagi organisasi, dimana pada hakekatnya berfungsi sebagai faktor penggerak bagi setiap kegiatan organisasi atau perusahaan. Oleh karena itu, di dalam organisasi sangatlah dibutuhkan manajemen yang baik, terutama sumber daya manusianya yakni karyawan. Peran karyawan sangat menentukan berhasil tidaknya perusahaan dalam mencapai tujuannya.

Sebagaimana telah diketahui bahwa pembukaan cabang PT. Taspen (Persero) digunakan untuk melayani pensiunan pegawai negeri sipil, sehingga hasil kinerja para pegawai sangat menentukan tingkat kepuasan konsumen yang dilayani perusahaan dan juga keberhasilan penyelenggaraan program Taspen daerah. Pencapaian hasil kinerja yang baik tidaklah hanya sebatas mampu menyelesaikan tugas yang di bebankan kepada para pegawai tepat pada waktu, tetapi hasil kinerja yang baik juga haruslah sesuai dengan indikator-indikator tentang kinerja yang ada.

Berdasarkan pengamatan sementara dan wawancara dengan Pimpinan, maka dapat penulis paparkan mengenai kinerja pegawai PT. Taspen 
(Persero) Cabang Pematangsiantar, yaitu: masih ada kinerja pegawai yang kurang baik, dimana yang menjadi masalah yaitu mengenai kehadiran, ketepatan waktu dari hasil, dan kualitas dari hasil. Hal ini dapat dilihat dari tingkat absensi/kehadiran pegawai dimana masih ada beberapa pegawai yang datang terlambat, kualitas dari hasil dan ketepatan waktu dari hasil. Dari jumlah pegawai PT. Taspen yang berjumlah sebanyak 30 orang, dimana 5 orang $(16,7 \%)$ diantaranya masih sering terlambat masuk kantor, selanjutnya terdapat 4 orang $(13,3 \%)$ yang kualitas dari hasil yang diperoleh rendah dan ada 4 orang $(13,3 \%)$ yang ketepatan kerja dari hasilnya masih rendah.

Untuk meningkatkan kinerja para pegawai perusahaan dipengaruhi oleh beberapa faktor seperti motivasi, kepemimpinan, kompensasi, lingkungan pekerjaan, dan salah satunya adalah stres kerja. Jika pegawai mengalami stres kerja yang tinggi, maka kinerja pegawai dapat menurun. Stres kerja yang dialami pegawai PT. Taspen (Persero) Cabang Pematangsiantar dapat berasal dari faktor interpersonal, tampilan rumah terhadap pekerjaan yang mengakibatkan tidak konsentrasi dalam bekerja ketika memiliki masalah pribadi, sehingga para pegawai lebih cenderung mengurus masalah pribadi dan mengabaikan pekerjaan ataupun jadi datang terlambat ke kantor. Dan hal ini mempengaruhi kinerjanya.

Oleh karena itu dibutuhkan ketegasan dari Pimpinan perusahaan untuk menegur para pegawai yang datang terlambat, kurang disiplin dalam melakukan pekerjaan dan memotivasi pegawai agar dapat merubah sikap agar lebih disiplin. Pimpinan juga perlu menciptakan suasana kerja yang nyaman dan penuh rasa kekeluargaan untuk mengurangi stres para pegawai, sehingga kinerja pegawai pun akan lebih baik.

\section{Rumusan Masalah}

a. Bagaimana gambaran tingkat stres kerja yang dialami pegawai dan gambaran kinerja pegawai pada PT. Taspen (Persero) Cabang Pematangsiantar?

b. Seberapa besar pengaruh stres kerja terhadap kinerja pegawai pada PT. Taspen (Persero) Cabang Pematangsiantar?

\section{Tujuan Penelitian}

a. Untuk mengetahui gambaran tingkat stres kerja yang dialami pegawai dan gambaran kinerja pegawai pada PT. Taspen (Persero) Cabang Pematangsiantar.

b. Untuk mengetahui besarnya pengaruh stres kerja terhadap kinerja pegawai pada PT. Taspen (Persero) Cabang Pematangsiantar.

\section{Metode Penelitian}

Tempat penelitian ini yaitu di PT. Dana Tabungan dan Asuransi Pegawai Negeri (Persero) yang berlokasi di Jalan Sisingamangaraja No. 98 Pematangsiantar. Populasi dalam melakukan penelitian ini adalah seluruh pegawai PT. Taspen
(Persero) Cabang Pematangsiantar yaitu sebanyak 30 orang dengan mengambil keseluruhan populasi menjadi sampel yang berjumlah 30 orang dikarenakan populasi jumlahnya kurang dari 100 orang dan mengingat ketersediaan waktu dan tenaga. Adapun Desain penelitian yang digunakan dalam penulisan skripsi ini adalah Penelitian Kepustakaan (Library Research) dan Penelitian Lapangan (Field Research). Teknik pengumpulan data yang dilakukan penulis dalam penelitian ini adalah berupa Kuesioner, Wawancara dan Dokumentasi. Adapun jenis data yang digunakan dalam penelitian ini adalah jenis data kualitatif dan data kuantitatif. Hasil data yang diperoleh dari lapangan akan dianalisis secara deskriptif baik bersifat kualitatif dan kuantitatif.

\section{B. LANDASAN TEORI}

Menurut Griffin (2004:8) manajemen adalah suatu rangkaian aktifitas (termasuk perencanaan dan pengambilan keputusan, pengorganisasian, kepemimpinan dan pengendalian) yang diarahkan pada sumber-sumber daya organisasi (manusia, finansial, fisik dan informasi) untuk mencapai tujuan organisasi dengan cara yang efektif dan efisien. Menurut Simamora (2004:4), manajemen merupakan proses pendayagunaan bahan baku dan sumber daya manusia untuk mencapai tujuan yang ditetapkan. Berdasarkan beberapa definisi di atas maka penulis membuat kesimpulan bahwa manajemen merupakan suatu kegiatan atau proses untuk mengatur dan mengendalikan sumber daya perusahaan yang ada secara efektif dan efisien guna tercapainya tujuan organisasi.

Pada dasarnya setiap organisasi berupaya untuk mencapai tujuannya. Untuk mencapai tujuan tersebut maka dibutuhkan peranan besar dari manusia. Manusia sebagai pelaku utama dalam aktivitas perusahaan, pada akhirnya menimbulkan kesadaran akan betapa pentingnya peranan sumber daya manusia dengan segala keinginan, kebutuhan dan harapan baik secara fisik maupun mental. Hal inilah yang mendorong munculnya satu cabang ilmu manajemen sumber daya manusia (MSDM). Menurut Dessler (2004:2), Manajemen Sumber Daya Manusia adalah kebijakan dan cara-cara yang dipraktekkan dan berhubungan dengan pemberdayaan manusia atau aspek-aspek sumber daya manusia dari sebuah posisi manajemen termasuk perekrutan, seleksi, pelatihan, penghargaan dan penilaian.

Fungsi manajemen sumber daya manusia menurut Mondy (2008:5) pada dasarnya ada lima jenis yaitu:

1. Penyediaan staf

Merupakan proses yang menjamin suatu organisasi untuk selalu memiliki jumlah karyawan yang tepat dengan keahlian-keahlian yang memadai dalam pekerjaan-pekerjaan tepat pada waktunya untuk mencapai tujuan organisasi.

2. Pengembangan sumber daya manusia

Fungsi manajemen sumber daya manusia utama yang tidak hanya terdiri atas pelatihan dan 
pengembangan namun juga aktivitas-aktivitas perencanaan dan pengembangan karier individu, organisasi, serta manajemen dan penilaian kinerja.

3. Kompensasi

Suatu sistem kompensasi yang terencana matang memberi para karyawan imbalan-imbalan yang layak dan andil atas kontribusi mereka dalam mencapai tujuan-tujuan organisasi.

4. Kesehatan Dan Keselamatan

Keselamatan adalah perlindungan bagi para karyawan yang disebabkan kecelakaankecelakaan yang terkait dengan pekerjaan. Kesehatan adalah bebasnya para karyawan dari sakit fisik atau emosi.

5. Hubungan Kekaryawanan Dan Perburuhan

Hubungan karyawan dengan pihak perusahaan harus lah dijaga dengan baik, agar karyawan lebih termotivasi untuk menacapai tujuan perusahaan yang telah di tetapkan.

Menurut Anoraga (2001:108), stres kerja adalah suatu bentuk tanggapan seseorang, baik fisik maupun mental terhadap suatu perubahan di lingkungannya yang dirasakan mengganggu dan mengakibatkan dirinya terancam. Terjadinya stres kerja adalah dikarenakan adanya ketidakseimbangan antara karakteristik kepribadian karyawan dengan karakteristik aspek-aspek pekerjaannya dan dapat terjadi pada semua kondisi pekerjaan.

Menurut Robbins (2002:794) ada tiga faktor penyebab stres kerja, yaitu:

1) Faktor Lingkungan

a) Perubahan situasi bisnis yang menciptakan ketidakpastian ekonomi. Bila perekonomian itu menjadi menurun, orang menjadi semakin mencemaskan kesejahteraan mereka.

b) Situasi politik yang tidak menentu seperti yang terjadi di Indonesia, banyak sekali demonstrasi dari berbagai kalangan yang tidak puas dengan keadaan mereka. Kejadian semacam ini dapat membuat orang merasa tidak nyaman. Seperti penutupan jalan karena ada yang berdemo atau mogoknya angkutan umum dan membuat para karyawan terlambat masuk kerja.

c) Kemajuan teknologi. Dengan kemajuan teknologi yang pesat, maka hotel pun menambah peralatan baru atau membuat sistem baru. Yang membuat karyawan harus mempelajari dari awal dan menyesuaikan diri dengan itu.

2) Faktor Organisasi

a) Tuntutan tugas merupakan faktor yang terkait dengan tuntutan atau tekanan untuk menunaikan tugasnya secara baik dan benar.

b) Tuntutan peran berhubungan dengan tekanan yang diberikan pada seseorang sebagai fungsi dari peran tertentu yang dimainkan dalam organisasi itu.

c) Tuntutan antar pribadi adalah tekanan yang diciptakan oleh karyawan lain. Kurangnya dukungan sosial dari rekan-rekan dan hubungan antar pribadi buruk dapat menimbulkan stres yang cukup besar, khususnya di antara para karyawan yang memiliki kebutuhan sosial yang tinggi.

d) Struktur Organisasi menentukan tingkat diferensiasi dalam organisasi, tingkat aturan dan peraturan dan dimana keputusan itu diambil. Aturan yang berlebihan dan kurangnya berpartisipasi dalam pengambilan keputusan yang berdampak pada karyawan merupakan potensi sumber stres.

3) Faktor Individu

a) Faktor persoalan keluarga. Survei nasional secara konsisten menunjukkan bahwa orang menganggap bahwa hubungan pribadi dan keluarga sebagai sesuatu yang sangat berharga.

b) Masalah Ekonomi. Diciptakan oleh individu yang tidak dapat mengelola sumber daya keuangan mereka merupakan satu contoh kesulitan pribadi yang dapat menciptakan stres bagi karyawan dan mengalihkan perhatian mereka dalam bekerja.

c) Karakteristik kepribadian bawaan. Faktor individu yang penting mempengaruhi stres adalah kodrat kecenderungan dasar seseorang. Artinya gejala stres yang diungkapkan pada pekerjaan itu sebenarnya berasal dari dalam kepribadian orang tersebut.

Menurut Wibowo (2007:123) kinerja berasal dari pengertian performance, kinerja merupakan hasil pekerjaan yang mempunyai hubungan kuat dengan tujuan strategis organisasi, kepuasan konsumen, dan memberikan kontribusi pada ekonomi. Kinerja juga merupakan tentang melakukan pekerjaan dan hasil yang dicapai dari pekerjaan tersebut. Kinerja karyawan yang meningkat akan turut mempengaruhi atau meningkatan prestasi organisasi yang telah ditentukan dapat tercapai.

Menurut Mahmudi (2005:36), faktor-faktor yang mempengaruhi kinerja karyawan, antara lain:

1) Faktor Individu/Personal yang meliputi pengetahuan, keterampilan, kemampuan, kepercayaan diri, motivasi dan komitmen yang dimiliki oleh setiap individu.

2) Faktor Kepemimpinan yang meliputi kualitas dalam memberikan dorongan, semangat, arahan dan dukungan yang diberikan manajer dan team leader.

3) Faktor Tim meliputi kualitas dukungan dan semangat yang diberikan oleh rekan dalam satu tim, kepercayaan terhadap sesama anggota tim, kekompakan dan keeratan anggota lain.

4) Faktor Sistem meliputi sistem kerja, fasilitas kerja atau infrastruktur yang diberikan oleh organisasi, proses organisasi dan kultur kinerja dalam organisasi.

5) Faktor Konstektual meliputi tekanan dan perubahan lingkungan ekternal dan internal.

Masalah stres pada dasarnya sering dikaitkan dengan pengertian stres kerja yang terjadi di lingkungan pekerjaan, yaitu dalam proses interaksi antara seorang karyawan dengan pekerjaannya, 
karena dampak stres di tempat kerja dapat mempengaruhi kehidupan, kesehatan, produktivitas dan penghasilan. Menurut Siagian (2008:302), tidak dapat disangkal bahwa stres yang tidak teratasi pasti berpengaruh terhadap prestasi atau kinerja karyawan. Dimana, tingkat stres yang tinggi atau stres ringan yang berkepanjangan akan menyebabkan menurunnya kinerja karyawan. Secara sederhana hal ini berarti bahwa stres mempunyai potensi untuk mendorong atau mengganggu pelaksanaan kerja, tergantung seberapa besar tingkat stres.

Apabila stres menjadi terlalu besar, prestasi kerja akan mulai menurun, karena stres mengganggu pelaksanaan pekerjaan. Karyawan kehilangan kemampuan untuk mengendalikannya, menjadi tidak mampu untuk mengambil keputusan-keputusan dan perilakunya menjadi tidak teratur. Akibat paling ekstrim adalah prestasi kerja menjadi nol, karena karyawan menjadi sakit atau tidak kuat bekerja lagi, putus asa, keluar dari pekerjaan, dan mungkin diberhentikan. Hal ini sangat berpengaruh terhadap tingkat kinerja karyawan.

\section{PEMBAHASAN}

\section{Analisa}

a. Deskriptif Kualitatif

Analisis deskriptif dimaksudkan untuk mendapatkan gambaran mengenai tanggapan dari responden mengenai variabel stres dan kinerja pegawai pada PT. Taspen (Persero) Cabang Pematangsiantar. Sesudah pengujian data, maka langkah selanjutnya peneliti melakukan pengkajian analisis deskriptif kualitatif sebagai gambaran fenomena dari variabel penelitian saat sekarang ini.

\section{1) Gambaran Tingkat Stres Kerja Pegawai PT} Taspen (Persero) Cabang Pematangsiantar

Stres kerja adalah suatu perasaan yang menekan atau rasa tertekan yang dialami karyawan dalam menghadapi pekerjaannya. Berdasarkan hasil analisa kuesioner dapat dilihat bahwa sebagian besar responden menjawab rendah dan sangat rendah dengan dimensi stres yang ada pada PT. Taspen (Persero) Cabang Pematangsiantar. Maka dapat diketahui bahwa jawaban atas dimensi kondisi pekerjaan, suasana ruang kerja saya kurang kondusif, 4,40 yakni sangat rendah, hal ini karena suasana kerja yang ada di PT. Taspen (Persero) Cabang Pematangsiantar sudah cukup kondusif. Adapun untuk kategori konsentrasi saya saat sedang melakukan pekerjaan, 3,83 yakni rendah, hal ini karena sebagian pegawai kurang berkonsentrasi dalam bekerja saat memiliki masalah pribadi.

Selanjutnya untuk dimensi stres karena peran, dalam kuesioner pendapat saya dalam rapat kurang mendapat tanggapan, 4,00 yakni rendah, hal ini menunjukkan bahwa pimpinan perusahaan selalu mendegarkan masukan ataupun saran yang membangun dari para bawahannya. Sedangkan untuk kuesioner tanggung jawab saya kurang atas tugas yang menyangkut bidang jabatan saya, 4,33 yakni sangat rendah, hal ini karena para pegawai PT. Taspen (Persero) Cabang Pematangsiantar memiliki rasa tanggung jawab terhadap tugas yang dibebankan kepadanya.

Dimensi hubungan interpersonal dalam hal ini hubungan kerjasama dengan rekan kerja kurang baik, 4,16 yakni rendah, karena para pegawai PT. Taspen (Persero) Cabang Pematangsiantar mampu menjalin kerjasama yang baik sesama rekan kerja. Sedangkan hubungan kerjasama dengan pimpinan terjalin kurang baik, 4,10 yakni rendah, karena pimpinan PT. Taspen (Persero) Cabang Pematangsiantar menjalin komunikasi dan kerjasama yang baik dengan para pegawainya.

Dalam hal dimensi perkembangan karir, untuk kuesioner peluang promosi jabatan kurang tersedia, 4,00 yakni rendah, hal ini dikarenakan pegawai yang memiliki kinerja yang baik mendapat kesempatan untuk promosi jabatan dari atasan. Dan untuk posisi jabatan saya kurang sesuai dengan keahlian saya, 4,16 yakni rendah, ini juga menunjukkan bahwa para pegawai PT. Taspen (Persero) Cabang Pematangsiantar ditempatkan sesuai dengan keahlian masing-masing para pegawai.

Sedangkan untuk dimensi struktur organisasi, untuk kuesioner pengawasan pimpinan terhadap pegawai kurang baik, 3,86 yakni rendah, hal ini dikarenakan pimpinan PT. Taspen (Persero) Cabang Pematangsiantar selalu melakukan pengawasan terhadap pegawainya. Untuk kuesioner saya kurang terlibat dalam pengambilan keputusan suatu kebijakan informasi, 4,03 yakni rendah, karena pimpinan perusahaan memberikan kesempatan kepada para bawahannya untuk memberikan pendapatnya sebelum mengambil keputusan.

Untuk dimensi tampilan rumah terhadap pekerjaan dengan kuesioner saya merasa tidak konsentrasi apabila sedang mengalami masalah pribadi, 3,26 yakni cukup rendah. Hal ini dikarenakan sebagian para pegawai PT. Taspen (Persero) Cabang Pematangsiantar dapat membedakan masalah pribadi dengan tugas kantor, namun masih ada juga pegawai yang kurang fleksibel, tidak dapat membedakan masalah pribadi dengan masalah kantor. Dan untuk keluarga kurang mendukung karir saya, 4,30 yakni sangat rendah, karena keluarga para pegawai mendukung penuh karir para pegawai PT. Taspen (Persero) Cabang Pematangsiantar.

\section{2) Gambaran Kinerja Pegawai PT. Taspen} (Persero) Cabang Pematangsiantar

Kinerja adalah hasil pekerjaan yang mempunyai hubungan kuat dengan tujuan strategis organisasi, kepuasan konsumen, dan memberikan kontribusi pada ekonomi. Kinerja juga merupakan tentang melakukan pekerjaan dan hasil yang dicapai dari pekerjaan tersebut. Berdasarkan hasil analisa kuesioner dapat dilihat bahwa kinerja pegawai pada PT. Taspen (Persero) Cabang Pematangsiantar telah dilakukan dengan cukup baik, hal ini dapat dilihat dari tabel rekapitulasi jawaban responden mengenai kinerja, dimana dari tabel tersebut dapat dilihat nilai intervalnya berada pada posisi sangat tinggi. 
Untuk kuesioner kuantitas hasil kerja yang saya capai setiap harinya sesuai dengan yang telah ditetapkan, 4,23 yakni sangat tinggi, sedangkan untuk kuesioner kuantitas hasil kerja saya setiap bulannya sesuai dengan yang ditetapkan perusahaan, 4,16 yakni tinggi. Dari jawaban responden tersebut dapat disimpulkan bahwa kuantitas kerja pegawai yang telah ditetapkan sebelumnya dapat dicapai oleh para pegawai PT. Taspen (Persero) Cabang Pematangsiantar.

Selanjutnya untuk dimensi kualitas dari hasil, kuesioner saya selalu memaksimalkan kualitas dari hasil pekerjaan, 4,36 yakni sangat tinggi. Sedangkan untuk kuesioner saya menyelesaikan pekerjaan sesuai dengan waktu yang ditetapkan, dengan kualitas kerja yang baik, 4,33 yakni sangat tinggi. Hal ini disebabkan pegawai PT. Taspen (Persero) Cabang Pematangsiantar dalam melaksanakan tugas selalu berusaha memberikan hasil kerja dengan kualitas yang baik, walaupun masih ada pegawai yang kurang memperhatikan hal ini.

Dimensi ketepatan waktu dari hasil, dalam kuesioner saya selalu menyelesaikan tugas sesuai dengan waktu yang ditetapkan, 4,30 yakni sangat tinggi.. Sedangkan untuk kuesioner penyelesaian tugas yang saya kerjakan semakin baik, dan selalu sesuai dengan waktu yang ditetapkan, 4,46 yakni sangat tinggi. Hal ini disebabkan karena para pegawai PT. Taspen (Persero) Cabang Pematangsiantar cukup efektif dan efesien dalam melakukan pekerjaannya.

Sedangkan untuk dimensi kehadiran, yang dalam kuesioner saya selalu datang ke kantor sebelum jam masuk kantor setiap harinya, 4,30 yakni sangat tinggi, dan kuesioner saya masuk kantor setelah selesai waktu istirahat, sesuai dengan jam masuk kantor, 4,56 yakni sangat tinggi. Dari nilai rata-rata tersebut dapat dilihat bahwa kehadiran pegawai PT. Taspen (Persero) Cabang Pematangsiantar berada pada kategori baik, namun masih ada juga pegawai yang datang terlambat, hal ini perlu diperhatikan oleh pimpinan, untuk lebih memperhatikan tingkat kedisiplinan kehadiran para pegawainya..

Untuk dimensi kemampuan bekerjasama, dalam kuesioner saya melakukan kerjasama dalam perusahaan, 4,36 yakni sangat tinggi, dan untuk kuesioner kerjasama antar pegawai di tempat saya bekerja terjalin dengan baik, 4,36 yakni sangat tinggi. Hal ini dikarenakan hubungan interpersonal antar para pegawai terjalin dengan baik.

\section{b. Deskriptif Kuantitatif}

\section{1) Analisa Regresi Linear Sederhana}

Analisis regresi linear sederhana dilakukan untuk melihat pengaruh yang terjadi diantara kedua variabel, dan juga befungsi sebagai penunjuk arah hubungan yang terjadi antara variabel dependen dan variabel independen. Untuk melihat apakah ada pengaruh stres terhadap kinerja pada PT. Taspen (Persero) Cabang Pematangsiantar digunakan analisis regresi linier sederhana, persamaan regresinya adalah sebagai berikut:
$\hat{\mathrm{Y}}=\mathrm{a}+\mathrm{bx}$

Persamaan regresinya adalah sebagai berikut:

$$
\begin{aligned}
& \overline{\mathrm{x}}=\frac{698}{30}=23,26 \\
& \overline{\mathrm{Y}}=\frac{1.307}{30}=43,56 \\
& \mathrm{~b}=\frac{\mathrm{n}\left(\sum \mathrm{XY}\right)-\left(\sum \mathrm{X}\right)\left(\sum \mathrm{Y}\right)}{\mathrm{n}\left(\mathrm{X}^{2}\right)-\left(\sum \mathrm{X}\right)^{2}} \\
& \mathrm{~b}=\frac{30(30.192)-(698)(1.307)}{30(16.357)-(698)^{2}} \\
& \mathrm{~b}=\frac{905.760-912.286}{490.710-487.204} \\
& \mathrm{~b}=\frac{-6.526}{3.506} \\
& \mathrm{~b}=-1,86 \\
& \mathrm{a}=\overline{\mathrm{Y}}-\mathrm{b} \overline{\mathrm{X}} \\
& \mathrm{a}=43,56-(-1,86)(23,26) \\
& \mathrm{a}=0,27
\end{aligned}
$$

Dari perhitungan di atas, maka persamaan (model) regresinya adalah: $\hat{Y}=0,27-1,86 \mathrm{X}$, artinya terdapat pengaruh negatif antara stres kerja terhadap kinerja. Jika tidak ada variabel stres kerja maka kinerja nilainya 0,27 , dan setiap penambahan 1 satuan stres kerja, berakibat pada penurunan kinerja sebesar 1,86. Atau dengan kata lain, semakin tinggi tingkat stres kerja pegawai berakibat pada semakin rendahnya kinerja pegawai, atau sebaliknya, semakin rendah tingkat stres kerja pegawai akan meningkatkan kinerja pegawai.

\section{2) Analisa Korelasi dan Determinasi}

Untuk mengukur kekuatan hubungan antara stres kerja dengan kinerja pegawai pada PT. Taspen (Persero) Cabang Pematangsiantar menggunakan teknik korelasi pearson dimana menurut Supranto (2001:201), pengukuran dirumuskan sebagai berikut:

$$
\begin{aligned}
& \mathrm{r}=\frac{\mathrm{n} \sum \mathrm{XY}-\sum \mathrm{X} \sum \mathrm{Y}}{\sqrt{n \sum \mathrm{X}^{2}-\left(\sum \mathrm{X}\right)^{2} \sqrt{\mathrm{n} \sum \mathrm{Y}^{2}-\sum(\mathrm{Y})^{2}}}} \\
& \mathrm{r}=\frac{30(30.192)-(1.307)(698)}{\sqrt{30(16.357)-(698)^{2} \sqrt{30(57.661)-(1.307)^{2}}}} \\
& \mathrm{r}=\frac{905.760-912.286}{\sqrt{490.710-487.204 \sqrt{1.729 .830-1.708 .249}}} \\
& \mathrm{r}=\frac{-6.526}{8.698,22} \\
& \mathrm{r}=-0,750
\end{aligned}
$$

Maka dari hasil perhitungan diperoleh $r=-0,750$ sehingga dapat diketahui hubungan antara stres kerja dengan kinerja kuat dan negatif. Hal ini dapat dilihat pada tabel interpretasi korelasi. Selanjutnya menggunakan perhitungan nilai koefisien determinasi yaitu: 


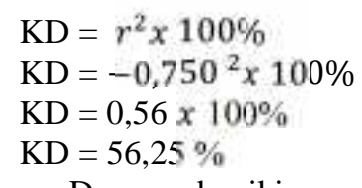

Dengan demikian menunjukkan bahwa tinggi rendahnya kinerja pegawai sekitar $56,25 \%$ dijelaskan oleh stres kerja, dan sisanya $43,75 \%$ dipengaruhi oleh faktor lain yang tidak dibahas dalam penelitian ini, seperti: motivasi, kepemimpinan, kompensasi, dan lain-lain.

\section{3) Uji Hipotesis}

Dari uji t, dapat membantu menunjukkan bagaimana sebuah variabel independen secara individual dalam menerangkan variabel dependen (signifikan apabila nilai t hitung > nilai tabel) dengan $\alpha=5 \%$.

Rumus yang digunakan:

$$
\mathrm{t}_{\text {hit }}=\frac{\mathrm{r} \sqrt{\mathrm{n}-\overline{2}}}{\sqrt{1-\mathrm{r}^{2}}}
$$

Dengan taraf signifikan a $5 \%$ maka $t$ tabel dengan rumus $t_{\alpha(n-2)}=t_{0,05(28)} \quad$ yaitu 2,048. Pengujiannya adalah:

$$
\begin{array}{rlr}
\mathrm{t}_{\text {hit }} & =\frac{\sqrt{\mathrm{n}-2}}{\sqrt{1-r^{2}}} \\
\mathrm{t}_{\text {hit }} & =\frac{-0.750}{\sqrt{1-1-(-0,750)^{2}}} & \mathrm{t}_{\text {hit }}<\mathrm{t}_{\text {tabel }} \\
\mathrm{t}_{\text {hit }} & =\frac{-3,968}{0,4365} & -9,090<-2,048 \\
\mathrm{t}_{\text {hit }} & =-\mathbf{9 , 0 9 0} & 9,090>2,048
\end{array}
$$

Hasil pengujian nilai $t_{\text {hitung }}$ sebesar 9,090 sedangkan $t_{\text {tabel(n-2) }}$ sebesar 2,048 pada tingkat kepercayaan $95 \%$ dan $\alpha=5 \%$. Oleh karena itu $t_{\text {hitung }}$ $>\mathrm{t}_{\text {tabel }}$, maka $\mathrm{H}_{0}$ ditolak dan Ha diterima, artinya stres kerja berpengaruh negatif terhadap kinerja pegawai pada PT. Taspen (Persero) Cabang Pematangsiantar.

\section{Evaluasi}

\section{a. Stres Kerja Pegawai PT. Taspen (Persero)}

\section{Cabang Pematangsiantar}

Berdasarkan dimensi yang digunakan untuk mengukur bagaimana stres yang terjadi pada PT taspen (Persero) Cabang Pematangsiantar, maka dari hasil penelitian yang diperoleh dapat dijelaskan bahwa stres yang terjadi rendah. Hal ini dibuktikan dari beberapa pernyataan yang ada di kuesioner yang ditanggapi dengan lebih banyak pernyataan "rendah" dari para pegawai PT. Taspen (Persero) Cabang Pematangsiantar.

Untuk manajemen stres kerja, baik oleh karyawan maupun pimpinan dapat melakukan strategi-strategi berikut ini:

1) Strategi Penanganan Individual

Yaitu strategi yang dikembangkan secara pribadi atau individual. Strategi individual ini bisa dilakukan dengan beberapa cara, antara lain: melakukan perubahan reaksi perilaku atau perubahan reaksi kognitif. Artinya, jika seorang karyawan merasa dirinya ada kenaikan ketegangan, para karyawan tersebut seharusnya beristirahat sejenak (time out) terlebih dahulu; melakukan relaksasi dan meditasi yang bisa dilakukan di rumah pada malam hari atau hari-hari libur kerja. Dengan melakukan relaksasi, karyawan dapat membangkitkan perasaan rileks dan nyaman.

2) Strategi-Strategi Penanganan Organisasional

Strategi ini didesain oleh manajemen untuk menghilangkan atau mengontrol penekan tingkat organisasional untuk mencegah atau mengurangi stres kerja untuk pekerja individual. Manajemen stres melalui organisasi dapat dilakukan dengan: menciptakan iklim organisasional yang mendukung, memperkaya desain tugas-tugas dengan memperkaya kerja baik dengan meningkatkan faktor isi pekerjaaan atau dengan meningkatkan karakteristik pekerjaan pusat seperti identitas tugas, mengurangi konflik dan mengklarifikasi peran organisasional.

3) Strategi Dukungan Sosial

Untuk mengurangi stres kerja, dibutuhkan dukungan sosial terutama orang yang terdekat, seperti keluarga, teman sekerja, pemimpin atau orang lain. Agar diperoleh dukungan maksimal, dibutuhkan komunikasi yang baik pada semua pihak, sehingga dapat menghindari terjadinya stres.

\section{b. Kinerja Pegawai PT. Taspen (Persero)} Cabang Pematangsiantar

Dari dimensi kinerja PT. Taspen (Persero) Cabang Pematangsiantar dapat dijelaskan bahwa dalam dimensi kuantitas dari hasil dinyatakan dengan tinggi, kualitas dari hasil juga dinyatakan dengan tinggi, namun masih ada pegawai yang memilih alternatif dua sebanyak dua orang responden. Hal ini dikarenakan masih ada pegawai yang datang terlambat masuk kantor, dan untuk mencapai hasil kerja yang ditetapkan, pegawai yang datang terlambat kurang memperhatikan kualitas dari hasil kinerjanya. Sehingga diperlukan ketegasan pimpinan dalam menegur pegawai yang datang terlambat, agar bisa datang lebih tepat waktu. Sehingga hasil kinerja pegawai akan lebih baik lagi ke depannya.

Pada dimensi ketepatan waktu dari hasil, pada umumnya pegawai melaksanakan pekerjaan tepat waktu adalah prioritas utama. Sedangkan dimensi kehadiran ditempat kerja, berdasarkan kuesioner para pegawai memilih tinggi, namun masih ada beberapa pegawai yang memilih alternatif satu sebanyak tiga orang. Dalam hal ini pimpinan perusahaan perlu lebih memotivasi dan menegur para pegawai agar datang lebih tepat waktu lagi ke kantor. Dan dimensi kemampuan bekerjasama, para pegawai lebih banyak memilih alternatif tinggi pada kuesioner yang dibagikan. Hal ini menunjukkan bahwa hubungan interpersonal antar pegawai terjalin dengan baik.

\section{KESIMPULAN DAN SARAN}

\section{Kesimpulan}

a. Dari hasil rekapitulasi tabel jawaban responden dapat disimpulkan bahwa stres kerja yang terjadi 
di PT. Taspen (Persero) Cabang Pematangsiantar rendah dan kinerja pegawai sangat tinggi.

b. Hasil perhitungan regresi yaitu $\hat{Y}=0,27-1,86 X$, artinya terdapat pengaruh negatif antara stres kerja terhadap kinerja, artinya semakin tinggi tingkat stres pegawai berakibat pada semakin rendahnya kinerja pegawai, atau sebaliknya, semakin rendah tingkat stres pegawai akan meningkatkan kinerja pegawai.

c. Dari perhitungan koefisien determinasi didapat nilai $r=-0,750$, bila dilihat dari tabel interpretasi berada pada interval kuat, sehingga dapat diketahui hubungan antara stres dengan kinerja kuat dan negatif. Dan nilai koefisien penentu sebesar 56,25\%, tinggi rendahnya kinerja pegawai dapat dijelaskan oleh stres kerja, dan sisanya $43,75 \%$ dipengaruhi faktor lain yang tidak dibahas dalam penelitian ini, seperti: motivasi, kepemimpinan, kompensasi, dan lainlain.

d. Hasil uji hipotesis pada taraf signifikan 5\% diperoleh nilai $t_{\text {hit }}$ sebesar 9,090 yang lebih besar dari $t_{\text {tabel }}$ yaitu 2,048. Ini berarti stres berpengaruh negatif terhadap kinerja pegawai pada PT. Taspen (Persero) Cabang Pematangsiantar.

\section{Saran}

a. Pimpinan perusahaan diharapkan untuk lebih memotivasi para pegawai agar lebih semangat dan lebih bertanggung jawab, serta menciptakan suasana kerja yang penuh dengan kekeluargaan dengan menjalin komunikasi yang baik dengan para pegawai, agar pegawai merasa nyaman dan lebih bersemangat dalam menyelesaikan tugastugasnya, sehingga hasil kinerja pegawai meningkat.

b. Pimpinan perusahaan diharapkan lebih tegas dalam menegur para pegawai yang sering datang terlambat ke kantor, dan yang memakai jam kerja kantor untuk mengurus masalah pribadi. c. Bagi pimpinan dan para pegawai diharapkan untuk memperhatikan teori strategi manajemen stres kerja dan karakteristik pegawai yang memiliki kinerja tinggi, untuk selanjutnya diterapkan di dalam diri masing-masing, guna mengatasi stres kerja dan juga meningkatkan kualitas diri.

d. Sehubungan dengan keterbatasan-keterbatasan yang ada pada penulis, penelitian ini belumlah sempurna untuk mengungkap faktor-faktor yang berhubungan dengan kinerja pegawai pada PT. Taspen (Persero) Cabang Pematangsiantar. Untuk itu, kepada peneliti selanjutnya agar meneliti faktor-faktor lain yang berhubungan dengan kinerja pegawai pada PT. Taspen (Persero) Cabang Pematangsiantar.

\section{E. DAFTAR PUSTAKA}

Anoraga, 2001, Psikologi Kerja, Jakarta : PT. Rineka Cipta.

Dessler G, 2004, Manajemen Sumber Daya Manusia, Jakarta : Prenhallindo

Griffin, Ricky W, 2004, Manajemen, Jilid 1, Edisi 7, Jakarta : Erlangga.

Mahmudi, 2005, Manajemen Kinerja Sektor Publik, Yogyakarta, UPP STIM YPKN.

Mondy, 2008, Manajemen Sumber Daya Manusia, Jilid 2, Edisi Kesepuluh, Jakarta: Erlangga.

Robbins, 2002, Prinsip-prinsip Perilaku Organisasi, Edisi Kelima, Jakarta: Erlangga.

Siagian, Sondang P, 2008, Manajemen Sumber Daya Manusia, Jakarta: PT. Bumi Aksara.

Simamora, Henry, 2004, Manajemen Sumber Daya Manusia, Yogyakarta: STIE YKPN.

Wibowo, 2007, Manajemen Kinerja, Edisi kedua, Jakarta: PT Raja Grafinso Persada. 